\title{
Responding the Constraints of Building Student- Teacher-Parent Relationships to Improve Student's Civic Disposition Phenomenological Studies in Civic Education Online Based Learning
}

\author{
Dwi Asih Triska Wardhani ${ }^{1, *}$, Susan Fitriasari ${ }^{2}$ \\ ${ }^{1,2}$ Universitas Pendidikan Indonesia, Bandung, Indonesia \\ *Corresponding author.Email: dwiwardhani@upi.edu
}

\begin{abstract}
Online learning provides a new pattern of relationships between students, teachers, and parents. There are various obstacles in building the right new relationship patterns. So that student's civic disposition have many challenges to improve. This article aims to explore how teachers, students, and parents respond the obstacles in building good relationships to improve student's civic disposition. The research method used is qualitative approach with phenomenological design. The data was collected with in-depth interviews and participant observations. The data is analyzed with transcription, horizonalisation, and cluster of meaning stages. Informants of this research are all teachers of Civic Education in Senior High School of Muhammadiyah Taman and representatives of students with their parents. The selection of informants is done by the snowball sampling technique. The result shows that students, teachers, and parents respond with several forms of action, namely: (1) maximizing limited time into quality time through dialogue or discussion, (2) simplifying demands, (3) including alternative options in difficult conditions, and (4) optimizing the use of communication technology. The conclusion is that both students, teachers, and parents respond to obstacles with full acceptance and awareness of the limitations on online learning during the pandemic along with continuous responsess to maximize their respective roles.
\end{abstract}

Keywords: Civic Disposition, Civic Education, Online Learning, Response, Student-Teacher-Parent Relationship.

\section{INTRODUCTION}

The changes that occurred during the pandemic present challenges for responsess to achieve educational goals. Education must have a dynamic structure and must adapt the substance of learning quickly in the face of changing conditions[1]. During the pandemic, Civic Education is expected to still be able to form sensitive individual characters and be able to motivate themselves to act appropriately in responding to environmental conditions. Civic Education learning based online as a form of implementation of distance learning get some challenges that also hinder responsess to improve civic disposition of students. Often government policies on the implementation of learning in the pandemic are not in line with the development of learning conducted by teachers[2].

When online learning becomes the only option so that teaching and learning activities can take place then there is a term forced readiness[3]. Forced readiness is a situation where online learning must still be done even though infrastructure and human resources capabilities have not been able to implement it. In addition, the problems encountered during learning from home in Indonesia are similar to the challenges of online learning according to Fielman, among others: (1) anxiety about the pandemic has an impact on the academic success of students, (2) Academic achievements of students are increasingly influenced by race, economic level, and resources owned, (3) most teachers are unable to provide instruction effectively and quality remotely[4].

That problems are strongly influenced by how the teacher's relationship with the students, especially in improving the character of the student's nationality. The relationship between teachers and students in learning greatly affects the mentality of students[5]. Mentally it affects students in perceiving their environment. Gradually the perception formed will become a character. If in Civic Education learning teachers can build a good relationship then civic disposition of students can be improved and learning objectives can be achieved more optimally. 
In online Civic Education-based learning with all its limitations, the role of parents increases in improving the character of students' citizenship. The problem is that during this pandemic parents are often less prepared to help. Therefore, the presence of parents needs to be emphasized in improving the civic disposition of students in online-based Civic Education learning. However, the relationship between students, teachers, and good parents will greatly influence success in improving the civic disposition of students.

Various obstacles in improving student's civic disposition during online learning were also found at SMA Muhammadiyah Taman. Based on the results of pre-research, both teachers, parents, and students experienced some obstacles in terms of improving student's civic disposition in Civic Education onlinebased learning. These constraints include limited learning time, difficulty in classroom management, supervision of student behavior, low learning enthusiasm, various violations of discipline, and decreased manners. Therefore, it takes a good relationship between students, teachers, and parents for these obstacles to be overcome. Based on current conditions and previous research, this article aims to study how are people responding the constraints of improving Student-Teacher-Parent Relationships in Civic Education online-based learning at Senior High School Muhammadiyah Taman.

\section{THEORETICAL RIVIEW}

\subsection{STPR on Online-Based Learning}

The quality of interpersonal relationships with others has a very significant influence on human behavior (Bandura 1986). Therefore, a good relationship between teachers and students must be built because it affects the mentality of students[5]. The construction of the Definition of Student-Teacher Relationship should emphasize the type of teacher interaction with personalized students, including the perception of students who view that teachers pay attention and respect them as individuals, sympathize and be able to see things from the student's perspective, and act as supporting figures that are responsive to the needs of students[6]

Families and schools are consciously set up with specific purposes for educating. Therefore parents and teachers are the ones who greatly influence the increase in civic disposition of students. Parents carry out their duty to educate children in the family. Because of the limitations of parents in educating children at home, and finally the education process was handed over at the school[7].

The relationship between students and teachers plays an important role in generating the passion for learning and bringing togetherness. This is because
STR is a relationship that is established due to the interaction between teachers and students as an emotion-based experience. The experience provides opportunities for students to learn social skills and settings or self-control and to practice basic developmental functions. The basic developments that can be developed with STR are attachment, exploration, play, and mastery[8].

In online learning during the pandemic, the relationship of teachers and students is not the only factor that plays an important role in improving student's civic disposition in Civic Education onlinebased learning. Parental involvement is an inseparable unity in the formal education process, especially as long as students do home learning in a platform conducted online. There is an urgency to build good relationships between teachers and students. Teacher-Parent Relationship has an important correlation with the academic development, career, and personal/social competency development of secondary school students. Families and schools need to work with each other to provide a supportive, enriching, close monitoring, and mentoring environment suitable for students[9].

On the other hand, online learning has a positive aspect that supports the existence of good STPR related to the improvement of student's civic disposition. Online-based learning can be conducted to monitor student performance and report student progress more easily[10]. The brotherhood can be an evaluation material for teachers and parents in motivating, guiding, and supervising students. Also, online-based learning can be enriched with applications that support civic disposition through aspects of knowledge as inputs in behaving.

\subsection{Civic Disposition in Civic Education}

Pancasila and Civic Education is part of the responsess to foster the nation and character building and empowerment of citizens[11]. Based on the explanation Civic Education includes three competencies of citizenship according to Bronson namely civic knowledge, civic skill, civic disposition. The civic competency studied in this study was civic disposition. Civic disposition is a personality of a nation as an important component in the sustainability of the country. The character of citizenship leads to the ownership and reflection of the private character (in the self) and the public character (interaction with the environment) that must exist in the citizen. The character becomes the basis of the maintenance and development of constitutional democracy as evidence of the proficiency/maturity of citizenship through the process of home lessons, schools, and social organizations[12].

Civic disposition contains individual personality 
characteristics as citizens namely civility (respect and civil discourse), individual responsibility, selfdiscipline, civic-mindedness, open-mindedness, (openness, skepticism, recognition of ambiguity), compromise (conflict of principles, compassion, generosity, and loyalty to the nation and its principles)[13]. The learning process of building civic disposition will be effective if developed through practical activities of students every day inside and outside the classroom[14].

\section{METHOD}

This research was conducted in SHS Muhammadiyah 1 Taman, Sidoarjo, Indonesia. SMA Muhammadiyah 1 Taman is the central Muhammadiyah High School in Sidoarjo Regency. In this school online learning is done in total so that there are no students in the school during the effective day. Total online-based learning improves the validity and accountability of research results.

This study uses a qualitative approach with the phenomenological method. The informant is selected with the characteristics:

Table 1. Short cut keys for the template

\begin{tabular}{|l|c|l|l|}
\hline Subject & $\begin{array}{l}\text { Innitial } \\
\text { Code }\end{array}$ & Gender & Detail Position/Job \\
\hline Student & S1 & Female & Tenth grader \\
\hline & S2 & Male & Tenth grader \\
\hline Teacher & S3 & Female & Eleventh grader \\
\hline & T2 & Female & Civic Education Teacher \\
\hline & T3 & Female & Civic Education Teacher \\
\hline Parent & P1 & Female & Housewife \\
\hline & P2 & Female & Enterpreneur \\
\hline & P3 & Female & Civil servant \\
\hline $\begin{array}{l}\text { Education } \\
\text { Expert }\end{array}$ & EX & Male & Professional/Lecturer \\
\hline
\end{tabular}

Research data is collected with in-depth interview techniques, observations, and documentation. Interviews conducted with informants the average time required is 70 minutes. Interviews with informants are conducted in Bahasa Indonesia so that informants can convey experiences, feelings, and understanding indepth related to phenomena. Furthermore, the results of the interview are translated into English without changing the meaning and wording of each sentence.

Data collection is done in schools and virtual spaces (online learning applications). Tools in data collection in the form of mobile phones, wireless, voice recorders, and sheet notes. Furthermore, the data is analyzed following the stages of data analysis in phenomenological studies, namely the stage of the description of phenomena, transcription of interview results, horizonalization stage, cluster of meaning (textural description and Structural description), essence description stage, and ended with the withdrawal of conclusions[15].

\section{RESULT AND DISCUSSION}

Responses to overcome obstacles in building relationships between students, teachers, and parents in improving the character of citizenship are carried out by each party in its capacity. Teachers make responses through the management of learning activities with a personal approach and using contextual learning strategies. In addition, teachers open wider communication opportunities for parents and students outside of learning using WhatsApp and learning apps.

Parents make responses to educate, motivate, facilitate, and supervise through daily life in accordance with the habits of each family. Both parents and teachers open the space and opportunity of interaction as widely as possible for all parties without any restrictions that hinder the improvement of the character of citizenship of students. Students also make responses in overcoming the obstacles of building STPR on online-based Civic Education learning instinctively and strongly influenced by the diversity of character characteristics that have. There is even a horizontal responses in building relationships with teachers, namely through inviting students to do the direction given by the teacher.

\subsection{Maximizing Limited Time into Quality Time through Dialogue or Discussion}

Improving the quality of STPR is pursued through enriching communication with substances that refer to the affective domain. Both teachers, parents, and students take advantage of the available time to discuss material and daily issues in $\mathrm{CE}$ online-based learning. Therefore, according to them, the very minimum intensity can be overcome by optimizing the existing opportunities with quality interactions.

The first responses is done with learning that activates students by multiplying discussion activities or dialogue through assignments, presentations, and discussions on citizenship issues. Breakthroughs must be made during the pandemic so that the interest and enthusiasm of students' learning can be improved. In addition, in this way aspects of citizenship character can be improved. Basically, discussions can strengthen the closeness between the parties by exchanging ideas so as to avoid misunderstandings.

In relation to learning practices, Martin \& Bolliger research shows the importance of creating interesting activities in an online learning environment[16]. This relates to engagement strategies that are considered 
important by students in improving the quality of online learning. Therefore, it can be known how important the strategy of teacher involvement in students, fellow students, and students with learning materials, and students in teachers.

T2 uses debate as part of improving dialogue. In learning Civic Education based online debate can be used as a proper learning activity in improving the character of the nationality of students. Debates can be effectively conducted on topics that have no right and wrong value. If the debate is conducted correctly, it can improve students' critical thinking skills, communication skills, collaboration skills, and engagement between students as well as the intensity of teacher and student interaction[17]. Debates in online learning can be leveraged to build effective virtual communities applied to a variety of disciplines and curricula[18].

On the other hand, parents use limited free time at night by discussing the wants, needs, and experiences of students. Busy work makes parents maximize limited time by sharing and communicating with students. In this communication it can be known that meaningful conversations arise that can help improve the character of the student's nationality even though it is not directly involved in online-based learning.

\subsection{Simplifying Demands}

The second responses is based on the principle of mutual respect and based on the idea that the capacity of students to do something cannot be equated with during normal conditions. Thus students, parents, and teachers can maintain good relationships because there are aspects of mutual understanding. In addition, this is necessary to reduce the possibility of conflict

In relation to simplification of demands, EX as an education expert highlights the steps to overcome the barriers to building relationships in improving the character of student citizenship during the pandemic;

"The revised 2018 curriculum design was not
initially known during the pandemic. When 2019 is
simplified then it will be the way out. The meaning
of simplified is not as ideal as before. Examples on
social attitudes in one semester appear KD has not
been elaborated into material and RPP. It should be
reduced where fundamental values are to be done.
Continued cooperation through technology can still
be like Zoom can be break out into small groups.
Children can enter by working together.
Technology can still facilitate for children to
develop a cooperation attitude"

Thus basically simplification of demands should start from downstream to upstream. Rational choices that can be taken by educators should be supported by systematic steps from substance to practical matters. Thus, both teachers, old prang, and students can still improve the character of citizenship of students in all limitations without objecting.

Furthermore, simplification of demands also needs to be done with changes in the strictness of discipline. Teachers admitted that there is a loosening of discipline applied between pandemics in anticipation of obstacles that arise. Basically violation of norms in terms of the theory of communitarian citizenship can be the reason for the decline of society. These setbacks in society can be overcome by fighting violations and returning the community to its original form.

Violation of norms or mutual agreement according to the theory of communitarian citizenship is a serious problem that will disrupt the existence and balance of society. Therefore, various violations are seen as behavior that must be opposed together[9]. Obeying values and norms as a form of avoiding violations is very important to be done by good citizens.

The values built in civic disposition through civic education are based on Pancasila. Pancasila and Citizenship education in this regard relates to the formation of the character of the nation that boils down to citizens. Because good citizens are reflected by individuals who have the robustness of the character of the nation or the character of the nation[19]. Therefore, Pancasila and Citizenship Education holds a great responsibility so that students adhere to the values and norms gathered in a regulation. There are three reasons why a person obeys the rules (1) The law commands something personally profitable, (2) The threat of punishment causes it is best to obey and (3) The subject feels a feeling of obligation or moral obligation[20].

While the results showed that teachers consider sanctions should be avoided except for severe violations. Teachers prefer rewarding students who have activeness. For teachers sanctions should not be used as an responses to improve the character of citizenship because it can be a reason for bad relations. In addition, the reason teachers do not sanction is that there are obstacles that arise outside the control of students. However, in essence sanctions are required under certain conditions because sanctions can give good to the behavior of students. The following are the functions of sanctions between; (1) Mobilize people to obey the law and prevent people from breaking it, and (2) Restoring the system of justice after the law is obeyed or violated[20].

Thus sunctions in the learning of Civic Education allowed to be done with educational purpose and good way. Sanctions will provide effective results against decreased violations if teachers, students, and parents have a good relationship. The reason is that interpersonal 
relationships affect a person's response to environmental influences[8]. In this case both teachers and parents are part of an important factor in the learning process of students where according to the environment has an influence in determining the social learning outcomes of students[21].

\subsection{Including Alternative Options in Difficult Conditions}

Including alternative options provides an opportunity to reduce misunderstandings resulting from indirect interactions that may present constraints during a pandemic. Such as network conditions, discipline in submitting assignments, or delays for reasons that can be tolerated. This responses is also carried out on the activities of students at home by parents. The following T3 statement relates to including alternatives in learning;

"I take the initiative not to give a heavy task. So his tasks are like making blogspot, discussion, oral daily replay. If they are still embarrassed can also daily replay with voice note"

The T3 decision is based on the view that there needs to be guidance without coercion and the actions of students must come from consideration from within. Responsess to improve civic disposition without forcing it aim to get individuals actively involved in developing functional patterns of thinking and behaving in response to environmental conditions to achieve personal goals.

Including alternatives in learning is a must considering each side is trying to go through different circumstances. The alternatives provided are accompanied by a simplification of demands and leniency of regulations. Distance learning shows fairness if the relationship between parties needs improvement. However, teachers need to take action as a preventive and repressive responses. Research conducted by Miler shows that educators practice authentic treatment and foster connectedness with: (1) Act as a warm request, (2) Responding to the socioemotional needs of students, and (3) Trying to bridge the digital divide[22].

Thus including alternative options in difficult conditions can be part of cultivating inclusion during online-based Civic Education learning. In this case the interaction between students and teachers can be done outside of learning hours and runs longer compared to face-to-face learning. The implication is that laternatives that can be given in a variety of circumstances become more varied.

\subsection{Optimizing The Use of Communication Technology}

Subsequent responsess relate to adjusting communication patterns during the pandemic. Students assess the teacher's citizenship education during online learning understands and provides opportunities for students who do light violations such as delays in following learning. It's not just about conveying the reason for the delay. Students are also allowed to contact the teacher regarding assignments and learning materials. In fact, both students and parents can send personal messages to teachers through online-based social networks. This is done because the informant feels that the learning time is very short to achieve learning objectives such as face-to-face learning. Therefore, even though at the actual time is no longer the operating hours of the school, teachers appreciate and consider that responding to personal messages from students and parents is a must.

Furthermore, with regard to space and time constraints, teachers open up space for students and parents to contact personally via WhatsApp outside of learning hours. This responses is in line with Berry's recommendation in the implementation of online learning based on the results of his research, teachers can organize joint learning in virtual classrooms to discuss learning materials and allow students to send private messages outside of lesson hours if there are certain obstacles or needs[23].

With the flow of personal communication opened by teachers, it can expand the teacher's reach to motivate, supervise, and guide students related to improving their civic character. On the other hand this method can be used to help meet the needs of students for more informal and synchronous peer interactions. So that teachers can help foster peer relationships that are important for the sense of belonging to the school[24]. Thus it will be easier to increase student participation in virtual communities. Indirectly communication will run better and engagement can be leveled. In addition, if there is a problem can be resolved immediately.

There are other altermatives to overcome the problem of space and time limitations in carrying out the function of educating and supervising students for teachers and parents. In the context of online learning, the presence of students in social life is necessary to build a public community where students can share ideas, receive feedback, improve critical thinking skills, and engage in group tasks[25][26]. Social media can be an alternative space that can help students improve their civic disposition through online-based activities in their daily lives. Through communication media such as video conferencing and messaging software support the occurrence of joint activities that encourage students to interact with each other in the online learning process[27]. 
Indirectly both teachers and parents can use social media as a space of supervision and education. Thus it is important to design meaningful learning activities by utilizing social media. $\mathrm{Ng} \& \mathrm{Chu}$ in his research revealed that teachers can maximize their role by building relationships through the social media activities of students[28]. Social media involvement in the educational process can help maintain the balance and health of academic and non-academic life of students.

The results of the study are in line with the results of Stone \& Logan research that students who use the social networking site WhatsApp as an informal learning space can foster a sense of connectedness. The benefits of using WhatsApp result from the freedom of the 'back channel' structure rather than the affordability and technological design of social networking services[29]. In addition, digital tools influence the level of interaction and impact student learning, crosscultural collaboration, and achievement in online learning.

\section{CONCLUSION}

Students, teachers, and parents respond to obstacles with full acceptance and awareness of the limitations on online learning during the pandemic along with continuous responsess to maximize their respective roles. In the current condition of increasing parental contribution and the quality of teacher interaction with students is an important aspect to be done. However during the pandemic student's civic disposition can still be improved through online civic education learning with the collaboration of the role of teachers, parents, and students appropriately.

Responsess to overcome obstacles in building relationships between students, teachers, and parents in improving the character of citizenship are carried out by each party in its capacity. Teachers make responsess through the management of learning activities with a personal approach and using contextual learning strategies Parents make responsess to educate, motivate, facilitate, and supervise through daily life in accordance with the habits of each family. Both parents and teachers open the space and opportunity of interaction as widely as possible for all parties without any restrictions that hinder the improvement of the character of citizenship of students. Students also make responsess in overcoming the obstacles of building STPR on onlinebased Civic Education learning instinctively and strongly influenced by the diversity of character characteristics that have. There is even a horizontal responses in building relationships with teachers, namely through inviting sesameapeserta students to do the direction given by the teacher.

\section{REFERENCES}

[1] M. Akbulut, U. Şahin, and A. C. Esen, "More than a virus: How COVID 19 infected education in Turkey?," J. Soc. Sci. Educ., vol. 19, no. Special Issue 1, pp. 30-42, 2020, doi: 10.4119/jsse-3490.

[2] K. Jones, "Notes on a Crisis: The Pandemic and English Schools," Chang. English Stud. Cult. Educ., vol. 27, no. 3, pp. 235-243, 2020, doi: 10.1080/1358684X.2020.1791691.

[3] R. M. Cutri, J. Mena, and E. F. Whiting, "Faculty readiness for online crisis teaching: transitioning to online teaching during the COVID-19 pandemic," Eur. J. Teach. Educ., vol. 43, no. 4, pp. 523-541, 2020, doi: 10.1080/02619768.2020.1815702.

[4] O. B. Adedoyin and E. Soykan, "Covid-19 pandemic and online learning: the challenges and opportunities," Interact. Learn. Environ., vol. 0, no. $0, \quad$ pp. 1-13, 2020, doi: 10.1080/10494820.2020.1813180.

[5] S. Schwab and P. Rossmann, "Peer integration, teacher-student relationships and the associations with depressive symptoms in secondary school students with and without special needs," Educ. Stud., vol. 46, no. 3, pp. 302-315, 2020, doi: 10.1080/03055698.2019.1584852.

[6] I. García-Moya, F. Brooks, and C. Moreno, "Humanizing and conducive to learning: an adolescent students' perspective on the central attributes of positive relationships with teachers," Eur. J. Psychol. Educ., vol. 35, no. 1, pp. 1-20, 2020, doi: 10.1007/s10212-019-00413-z.

[7] N. Wiyani and Barnawi, Ilmu Pendidikan Islam. Yogyakarta: Ar-Ruzz Media, 2012.

[8] R. C. Pianta, Enchancing Relationship Between Children And Teachers. Washington DC: American Pychological Association, 1999.

[9] L. Deng, N. Zhou, R. Nie, P. Jin, M. Yang, and X. Fang, "Parent-teacher partnership and high school students' development in mainland China: the mediating role of teacher-student relationship," Asia Pacific J. Educ., vol. 38, no. 1, pp. 15-31, 2018, doi: 10.1080/02188791.2017.1361904.

[10] L. Smaldino and Russel, Instructional Technology and Media Learning. Jakarta: Kencana Prenada Media Group, 2011.

[11] A. A. Wahab and Sapriya, Teori dan Landasan Pendidikan Kewarganegaraan. Bandung: Alfabeta, 2011.

[12] N. Branson, Belajar Civic Education Dari Amerika. Yogyakarta: Lembaga Kajian Islam dan Sosial (LKIS) dan The Asia Foundation (TAF), 1999.

[13] C. . Quigley, J. J. . Buchanan, and C. . Bahmueller, Civitas: A Framework for Civic Education. Calabas: CCE, 1991.

[14] S. Pasandaran, A. L. Lonto, T. Pangalila, and R. A. Barahama, "The Efforts of Civic Education Teachers in Strengthening Students' Civic 
Disposition," vol. 251, no. Acec, pp. 59-61, 2018, doi: 10.2991/acec-18.2018.14.

[15] Cresswel, RISET PENDIDIKAN: Perencanaan, Pelaksanaan, dan Evaluasi Riset Kualitatif \& Kuantitatif, Fifth edit. Yogyakarta: Pustaka Pelajar, 2015.

[16] F. Martin and D. U. Bolliger, "Engagement matters: Student perceptions on the importance of engagement strategies in the online learning environment," Online Learn. J., vol. 22, no. 1, pp. 205-222, 2018, doi: 10.24059/olj.v22i1.1092.

[17] E. T. Mitchell, "Using debate in an online asynchronous social policy course," Online Learn. J., vol. 23, no. 3, pp. 21-33, 2019, doi: 10.24059/olj.v23i3.2050.

[18] C. C. Chen and K. Swan, "Using innovative and scientifically-based debate to build e-learning community," Online Learn. J., vol. 24, no. 3, pp. 67-80, 2020, doi: 10.24059/olj.v24i3.2345.

[19] S. Al Muchtar, Ilmu Kewarganegaraan. Bandung: Laboratorium Pendidikan Kewarganegaraan UPI, 2019.

[20] W. Poespoprodjo, Filsafat Moral: Kesusilaan dalam Teori dan Praktik. Bandung: Pustaka Grafika, 1999.

[21] A. A. Bandura, A Social Cognitive Theory Of Personality, In L. Pervin \& O. John Handbook of Personality. New York: Guildford Publications, 1999.

[22] K. E. Miller, "A light in students' lives: K-12 teachers' experiences (re)building caring relationships during remote learning," Online Learn. J., vol. 25, no. 1, pp. 115-134, 2021, doi: 10.24059/olj.v25i1.2486.

[23] S. Berry, "Teaching to connect: Communitybuilding strategies for the virtual classroom," Online Learn. J., vol. 23, no. 1, pp. 164-183, 2019, doi: 10.24059/olj.v23i1.1425.

[24] S. Peacock and J. Cowan, "Promoting sense of belonging in online learning communities of inquiry in accredited courses," Online Learn. J., vol. 23, no. 2, pp. 67-81, 2019, doi: 10.24059/olj.v23i2.1488.

[25] M. G. Brown, "Blended instructional practice: A review of the empirical literature on instructors' adoption and use of online tools in face-to-face teaching," Internet High. Educ., vol. 31, pp. 1-10, 2016, doi: 10.1016/j.iheduc.2016.05.001.

[26] D. T. K. Ng, R. Reynolds, H. M. Y. Chan, X. H. Li, and S. K. W. Chu, "Business (Teaching) As Usual Amid The Covid-19 Pandemic: A Case Study Of Online Teaching Practice In Hong Kong," J. Inf. Technol. Educ. Res., vol. 19, pp. 777-802, 2019, doi: 10.28945/4620.

[27] J. Bell, S. Sawaya, and W. Cain, "Synchromodal Classes: Designing for Shared Learning Experiences Between Face-to-Face and Online Students," Int. J. Des. Learn., vol. 5, no. 1, pp. 68-82, 2014, doi: 10.14434/ijdl.v5i1.12657.

[28] D. T. K. Ng and S. K. W. Chu, "Motivating students to learn ai through social networking sites: A case study in Hong Kong," Online Learn. $J$., vol. 25, no. 1, pp. 195-208, 2021, doi: 10.24059/olj.v25i1.2454.

[29] S. Stone and A. Logan, "Exploring Students' Use of the Social Networking Site WhatsApp to foster connectedness in the online learning experience," Irish J. Technol. Enhanc. Learn., vol. 3, no. 1, pp. 42-55, 2018, doi: 10.22554/ijtel.v3i1.28. 